\title{
Screening and characterisation of potentially pathogenic bacteria associated with Atlantic cod Gadus morhua larvae: bath challenge trials using a multidish system
}

\author{
Nina Sandlund ${ }^{*}$, Øivind Bergh \\ Institute of Marine Research, PO Box 1870 Nordnes, 5817 Bergen, Norway
}

\begin{abstract}
In intensive aquaculture systems, high concentrations of nutrients and high densities of fish larvae provide favorable conditions for opportunistic pathogenic bacteria to flourish. We screened potentially pathogenic bacterial strains isolated from moribund Atlantic cod Gadus morhua larvae, pollack Pollachius pollachius, coalfish Pollachius virens, Atlantic halibut Hippoglossus hippoglossus, rotifers, algae and water samples from different hatcheries. Three identical challenge experiments tested a total of 53 strains. A multidish system was used: cod eggs were placed in single wells, together with $2 \mathrm{ml}$ of sterile seawater, and exposed to the bacterial cultures. Final bacterial concentrations in the wells were $10^{6}$ and $10^{4} \mathrm{CFU} \mathrm{m}{ }^{-1}$. Eggs and larvae not exposed to bacteria were used as unchallenged controls. Challenged controls were exposed to Vibrio anguillarum strain 610. Eggs were challenged approximately $48 \mathrm{~h}$ prior to hatching and mortality was recorded daily throughout the yolk-sac period. In spite of the high challenge dose of $10^{6} \mathrm{CFU} \mathrm{ml}{ }^{-1}$, only 5 bacterial strains tested caused higher mortality than the unchallenged controls. Four of these strains were identified by $16 \mathrm{~S}$ rDNA and gyrase B gene (GyrB) sequencing as resembling $V$. anguillarum and 1 strain resembled Carnobacterium sp. Most of the larvae exposed to these strains died within $10 \mathrm{~d}$ of challenge. Serotyping of the strains resembling $V$. anguillarum gave inconclusive results. This indicates differences in serology compared to the serotypes $\mathrm{O} 1, \mathrm{O} 2$ and O3, associated with disease. Three bacterial strains seemed to have a slower infection rate, indicating a longer incubation period. The remaining 45 strains did not seem to have a negative effect on larval survival, suggesting that these are not primary pathogens.
\end{abstract}

KEY WORDS: Screening $\cdot$ Cod larvae $\cdot$ Bath challenge $\cdot$ Opportunistic bacteria $\cdot$ Vibriosis $\cdot$ Vibrio anguillarum

\section{INTRODUCTION}

Atlantic cod Gadhus morhua L. aquaculture has been expanding rapidly in Norway since 2000 (Svåsand et al. 2004). In 2006, about 10384 tonnes of farmed cod (full life cycle) were slaughtered and 214 licenses for cod farming to 104 companies were operational (Directorate of Fisheries, Bergen, Norway. Available at: www.fiskeridir.no/fiskeridir/kystsone_og_havbruk/ statistikk/statistikk_for_akvakultur/torsk). Of these, 60 to 80 ongrowth farms and 15 to 20 hatcheries were in operation (Kongsvik 2007).

The production of juveniles has been a bottleneck in cod farming. Cod larvae have a relatively short yolk-sac stage and they start to consume live feed, i.e. rotifers and Artemia spp., around 3 to $4 \mathrm{~d}$ post-hatching. Rotifers and Artemia are filter-feeding organisms, capable of concentrating bacteria, and thus are a potential source of pathogenic bacteria in the larval rearing system. Larvae also ingest bacteria by drinking water. High larval densities 
and suboptimal rearing conditions may provide a good environment for opportunistic bacterial pathogens to flourish (Vadstein et al. 2004), and high rates of mortality are still common. Commercial enrichment diets for rotifers may enhance the growth of pathogens including Vibrio anguillarum (Korsnes et al. 2006). Adult cod are frequently subject to classical vibriosis caused by $V$. anguillarum (reviewed by Samuelsen et al. 2006). V. anguillarum is also known to cause high mortality in a variety of fish species (reviewed by Thompson et al. 2004a).

The epiflora of cod eggs seems to be dominated by members of the Cytophaga/Flavobacterium/Flexibacter group, while Vibrio spp. are not frequent (Hansen \& Olafsen 1989). In the past overgrowth of eggs was regarded as a problem; however, disinfection has reduced this (reviewed by Olafsen 2001).

While the composition of the intestinal bacterial flora associated with yolk-sac larvae of fish generally resembles the egg epibiota, a shift in the intestinal microbiota from a generally non-fermentative to a fermentative flora dominated by the Vibrio/Aeromonas group coincides with the onset of exogenous feeding (Vadstein et al. 2004). During first feeding, yolk-sac larvae in general are subject to a massive inflow of bacteria from the live feed organisms Brachionus plicatilis and Artemia spp., resulting in a shift in intestinal bacterial flora (Brunvold et al. 2007), and suspected pathogens such as $V$. anguillarum may accumulate in the live feed (Korsnes et al. 2006). The mucosal surfaces of fish serve as a substrate for bacterial adhesion (Spangaard et al. 2000) and thereby a potential portal of entry. Uptake of intact antigens from bacteria in the intestine of 4 to $6 \mathrm{~d}$ old yolk-sac larvae of cod has been demonstrated, and it has been suggested that this uptake may play a role in immune development, or in nutrition (Olafsen \& Hansen 1992).

Whether the bacteria are primary causes of mortality or secondary pathogens that take advantage of weakened larvae is disputed. An important step would be to test whether any of the bacterial strains found has the ability to cause disease. Knowledge concerning sources and species of bacteria most commonly associated with cod larvae at different life stages is essential. It is also important to know the amount of bacteria needed to induce infection. The objectives of this study were to screen a large number of bacterial strains associated with diseased cod larvae, other marine cold-water species and live feed cultures, and to test the virulence of the strains in a challenge model using cod yolk-sac larvae.

\section{MATERIALS AND METHODS}

Broodstock, eggs and larvae. Eggs were collected at the Sagafjord commercial cod hatchery, in the county of Hordaland, Norway $\left(59^{\circ} 45^{\prime} \mathrm{N}, 5^{\circ} 29^{\prime} \mathrm{E}\right)$. The broodstock originated from the Bømlo and Halsnøy area in the same county.

All eggs were taken from the same group. They were disinfected immediately after fertilisation in glutardialdehyde $300 \mathrm{ppm}$ for $10 \mathrm{~min}$, and kept in black conical $150 \mathrm{l}$ tanks at 6.5 to $7.0^{\circ} \mathrm{C}$. Eggs were transported from the hatchery to the Institute of Marine Research in boxes filled with ice, with the eggs stored in plastic bags. The transfer took about 2 to $3 \mathrm{~h}$.

Bacteria. A total of 117 bacterial isolates were collected: 85 isolates were isolated from dead or moribund cod Gadus morhua larvae, while 3 were isolated from pollack Pollachius pollachius, 2 from coalfish Pollachius virens and 13 from Atlantic halibut Hippoglossus hippoglossus fry, 3 from water samples, 4 from rotifer, Brachionus plicatilis and 3 from algal cultures of Tetraselmis sp. In addition, 1 strain was isolated from adult cod and 3 strains were isolated from salmon Salmo salar. To reduce the number of strains used, the growth patterns of all strains were compared on different growth media: marine agar (MA), thiosulphate citrate bile sucrose agar (TCBS) (Merck), Cytophaga medium (CA) (Whitman 2004) and blood agar (nutrient blood agar [Oxoid] supplemented with 5\% sheep blood and $1.5 \% \mathrm{NaCl}$ ). Comparison of $16 \mathrm{~S}$ rDNA sequences was also performed. All strains with similar growth patterns and similarities in 16S rDNA sequences greater than $97 \%$ (Hagström et al. 2000, 2002) were eliminated from the challenge trials (data not shown). A total of 53 different bacterial strains were selected for use in the 3 identical challenge experiments (see Table 1).

The challenge experiment included an unchallenged control (eggs and larvae not exposed to bacteria) and two challenged control groups (eggs and larvae challenged with Vibrio anguillarum strain 610, challenge dose $10^{6}$ and $10^{4} \mathrm{CFU} \mathrm{m}{ }^{-1}$ ). $V$. anguillarum strain 610 is known to cause high mortality in various fish species such as Atlantic cod Gadus morhua (Samuelsen \& Bergh 2004, Vik-Mo et al. 2005, Seljestokken et al. 2006) and Atlantic halibut Hippoglossus hippoglossus (Samuelsen et al. 1997) and is commonly used in our laboratory during challenge experiments.

All bacteria were stored at $-80^{\circ} \mathrm{C}$ in a $20 \%$ glycerol/ marine broth (MB) (Difco 2216) stock. They were incubated at $15^{\circ} \mathrm{C}$ and grown on petri dishes with Difco 2216 marine agar (MA) for $48 \mathrm{~h}$. Colonies of the bacteria were transferred to Erlenmeyer flasks with $50 \mathrm{ml}$ of $\mathrm{MB}$ and shaken at $80 \mathrm{rpm}$ in a shaking incubator (INFORS AG CH-4103) for $48 \mathrm{~h}$ at $7^{\circ} \mathrm{C}$. The bacterial cultures $(30 \mathrm{ml})$ were harvested by centrifugation (Heraeus Sepathec Megafuge $1.0 \mathrm{R}$ ) at $2772 \times g$ for $10 \mathrm{~min}$ at $4^{\circ} \mathrm{C}$, washed twice in $30 \mathrm{ml}$ phosphate- 
buffered saline (PBS) and suspended in $30 \mathrm{ml}$ PBS. The cell concentration was determined by counting, using a Hawksley counting chamber.

The Vibrio anguillarum strain 610 was originally isolated from cod suffering from vibriosis in the Parisvatnet research facility of the Institute of Marine Research (Øygarden municipality, Western Norway). Moritella viscosa was provided by Helene Mikkelsen at the Norwegian Institute of Fisheries and Aquaculture Research in Tromsø, and the strains F95B/98 and F95C/98 were provided by Anne Berit Olsen from the National Veterinary Institute in Bergen. Strains HI 21030 to HI 21069 were provided by Egil Karlsbakk at the Institute of Marine Research. These strains were all characterised by the above named researchers, except for the API results and the growth studies on TCBS and CA medium for HI 21030 to HI 21069.

Challenge experiments. Three identical challenge experiments were preformed. All eggs were exposed to bacteria approximately $48 \mathrm{~h}$ before hatching on Day 10 or Day 11 after fertilisation.

Eggs were randomly taken and transferred to 24-well polystyrene dishes (Nunc) by autoclaved Pasteur pipettes. The protocol was modified from Bergh et al. $(1992,1997)$. All eggs hatched within $10 \mathrm{~h}$, and 7841 of 7848 eggs hatched successfully. The eggs were put separately into individual wells containing $2.0 \mathrm{ml}$ of sterile $80 \%(28 \%)$ seawater. The seawater was aerated just before use to minimize the possibility of contamination. Exactly $100 \mu \mathrm{l}$ of bacterial suspension was added to each well. Final bacterial concentrations in the wells were $10^{6}$ and $10^{4} \mathrm{CFU} \mathrm{ml}{ }^{-1}$, respectively, for high- and low-challenge doses. Final volume in each well was $2.1 \mathrm{ml}$. Three plates (72 wells) were used for each bacterial concentration, thus 6 plates (144 wells) were used for each bacterial strain. Three plates with unchallenged larvae were used as negative controls. The eggs and larvae were incubated in darkness in a climate-controlled room at $7^{\circ} \mathrm{C}$. All eggs and larvae were inspected each day, for up to $18 \mathrm{~d}$, and mortality was registered.

API 20E (Biomérieux) tests were performed according to the manufacturer's manual, with the following modifications: bacterial cultures were dissolved in sterile physiological saline $(9 \mathrm{~g} \mathrm{NaCl}$ dissolved in $1 \mathrm{l}$ distilled water). The McFarland 2 standard was used as reference to culture density. The API strips were incubated at $15^{\circ} \mathrm{C}$ for $48 \mathrm{~h}$.

Gram staining was performed with the Diagnostica (Merck Gram) staining set.

Immunostaining of bacterial smears. To test some of the Vibrio anguillarum strains for serotype, bacterial smears of HI 21412, HI 21413, HI 21414 and HI 21429 were stained with specific absorbed polyclonal anti- serum against serotypes $\mathrm{O} 2 \alpha, \mathrm{O} 2 \beta$ and O1. All antisera were produced according to the method of Oeding (1957) and absorbed by the method of Knappskog et al. (1993). The antiserum against serotype O2 $\alpha$ was absorbed against $\mathrm{O} 2 \beta$ and $\mathrm{O} 1$, the antiserum against $\mathrm{O} 2 \beta$ was absorbed against $\mathrm{O} 1$ and the antiserum against $\mathrm{O} 1$ was absorbed against $\mathrm{O} 2 \beta$. All 3 antisera were diluted in tris-hydroxymethyl-aminomethane (Tris)buffered saline (TBS) with $2.5 \%$ bovine serum albumin (BSA). To prevent non-specific antibody binding, sections were blocked by using $5 \%$ BSA in TRIS-buffered formaldehyde for $20 \mathrm{~min}$. Avidin-biotin-alkaline phosphatase complex (ABComplex/AP) reaction kit and New Fuchsin Substrate system (Dako) were used according to the manufacturer's manual. During the staining procedures, the different bacterial strains were kept separate to prevent cross-contamination. During staining both positive and negative controls were used. Known O2 $\alpha$ (strain HI 610), O2 $\beta$ (strain HI 618) and $\mathrm{O} 1$ (strain HI 644) serotypes isolates were used as positive controls. The $\mathrm{O} 2 \alpha$ and $\mathrm{O} 2 \beta$ were used as negative controls during staining procedures; the $\mathrm{O} 1$ antiserum, $\mathrm{O} 2 \beta$ and $\mathrm{O} 1$ isolates were used when staining with $\mathrm{O} 2 \alpha$ antiserum, and $\mathrm{O} 2 \alpha$ and $\mathrm{O} 1$ isolates were used as negative controls when the $\mathrm{O} 2 \beta$ antiserum was used. All incubations were performed at room temperature $\left(20^{\circ} \mathrm{C}\right)$ in a humidity chamber.

Mono-Va agglutination kit against Vibrio anguillarum. Mono-Va tests (Bionor Laboratories) were used to identify the isolates $V$. anguillarum 610, HI 21412, HI 21413, HI 21414 and HI 21429. The test was done according to the manufacturer's manual.

DNA isolation. Genomic bacterial DNA was isolated from $1 \mathrm{ml}$ of a liquid culture harvested at the end of the exponential growth phase, using the purification kit DNeasy ${ }^{\circledR} 96$ tissue kit (Qiagen). The protocol for Gram negative bacteria was used.

Polymerase chain reaction (PCR) amplification of 16S rDNA genes. Universal primers, $27 \mathrm{f}$ and 1492r (Escherichia coli numbering), were used for $16 \mathrm{~S}$ rDNA analyses. The mix contained $2.0 \mu \mathrm{l}$ PCR buffer $(10 \times)$, $1.2 \mu \mathrm{MgCl}_{2}(25 \mathrm{mM}), 3.2 \mu \mathrm{l}$ dNTP $(1.25 \mathrm{mM}$ each, Promega), $1.0 \mu \mathrm{l} 27 \mathrm{f}$ forward primer $(10 \mu \mathrm{m}), 1.0 \mu \mathrm{l}$ 1492r reverse primer $(10 \mu \mathrm{m}), 0.2 \mu \mathrm{l}$ Taq polymerase

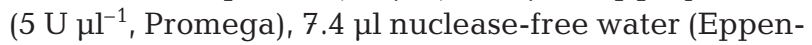

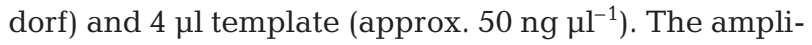
fication was performed in an automated thermal cycler (Perkin Elmer, Gene Amp, PCR system 9700) and the cycles were as follows: initial denaturation at $95^{\circ} \mathrm{C}$ for $5 \mathrm{~min}$, then 35 cycles of denaturation at $94^{\circ} \mathrm{C}$ for $1 \mathrm{~min}$, annealing at $55^{\circ} \mathrm{C}$ for $1 \mathrm{~min}$, and extension at $72^{\circ} \mathrm{C}$ for $11 \mathrm{~min}$. All PCR reactions were performed in $50 \mu \mathrm{l}$ reaction tubes.

PCR amplification of GyrB gene. Primers used for amplification of the GyrB gene were GyrB-1 (forward) 
and GyrB-2 (reverse) (Yamamoto \& Harayama 1995). The mix contained $2.0 \mu \mathrm{l}$ PCR buffer (10x), $1.5 \mu \mathrm{l}$ $\mathrm{MgCl}_{2}$ (25 mM), $4.0 \mu \mathrm{dNTP}$ (1.25 mM each, Promega), $1.0 \mu \mathrm{l}$ GyrB-1 primer $(10 \mu \mathrm{M}), 1.0 \mu \mathrm{l}$ GyrB-2 primer $(10$

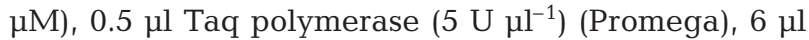
nuclease-free water (Eppendorf) and $4 \mu$ template (approx. $50 \mathrm{ng}^{-1} \mathrm{l}^{-1}$ ). The amplification cycle was as follows: initial denaturation at $95^{\circ} \mathrm{C}$ for $5 \mathrm{~min}$, then 35 cycles of denaturation at $94^{\circ} \mathrm{C}$ for $1 \mathrm{~min}$, annealing at $58^{\circ} \mathrm{C}$ for $1 \mathrm{~min}$, extension at $72^{\circ} \mathrm{C}$ for 2 min and extension/hold for $7 \mathrm{~min}$. The amplification was performed in an automated thermal cycler (Gene Amp PCR system 9700, Perkin Elmer).

Sequencing of $16 \mathrm{~S}$ rDNA and GyrB genes. All PCR products were prepared for sequencing by using a PreSequencing Kit (USB). One cycle of $37^{\circ} \mathrm{C}$ for $15 \mathrm{~min}$ and in addition, another $15 \mathrm{~min}$ at $80^{\circ} \mathrm{C}$ were run. Primers used for sequencing 16S rDNA genes were the same as for the PCR amplification described in the paragraph above. The pre-sequencing mix contained $1 \mu \mathrm{l}$ Big Dye mix $(2.5 \times$ ) (Big Dye version 3.1, Applied Biosystems), $1.5 \mu$ l sequence buffer $(5.0 \times), 2.0 \mu \mathrm{l}$ primer $(10 \mu \mathrm{M})$ and $2.5 \mu \mathrm{l}$ RNAse free water (Eppendorf) and $3 \mu \mathrm{l}$ of template were used. The amplification cycles were as follows: initial denaturation at $96^{\circ} \mathrm{C}$ for 1 min then 25 cycles of denaturation at $96^{\circ} \mathrm{C}$ for $10 \mathrm{~s}$, annealing at $50^{\circ} \mathrm{C}$ for $5 \mathrm{~s}$, and extension at $60^{\circ} \mathrm{C}$ for 4 min.

Primers used for sequencing GyrB genes were different from the ones used for PCR amplification: GyrB-1s (forward) and GyrB-2s (reverse) (Yamamoto \& Harayama 1995). The same pre-sequencing mix and amplification cycles as used for 16S rDNA genes were used on the sequencing of the GyrB genes as well. The amplification was performed in an automated thermal cycler (Gene Amp PCR system 9700, Perkin Elmer). The sequence analysis was performed by the sequence laboratory at the University of Bergen, using an ABI 3700 sequencing analyzer (Applied Biosystems). The 16S rRNA and GyrB encoding gene sequences were searched for nucleotide-nucleotide matches in the BLAST database at the NCBI (www.ncbi.nlm.nih.gov/ BLAST/) to establish tentative strain identity (Altschul et al. 1990).

Statistical analyses. Since the survival and mortality data were not normally distributed, non-parametric tests were used. A number of $2 \times 2$ contingency tables (performed using Statistica v 7.0, StatSoft) were used to examine rates of mortality in the treatment and control groups. Since multiple independent tests were used, the significance level was adjusted using the Bonferroni correction and set at $\mathrm{p}<0.00094$ (i.e. $\mathrm{p}=$ 0.05/53 number of tests performed) (Rice 1989). Additionally, Yates correction was used because there was only 1 degree of freedom (df).

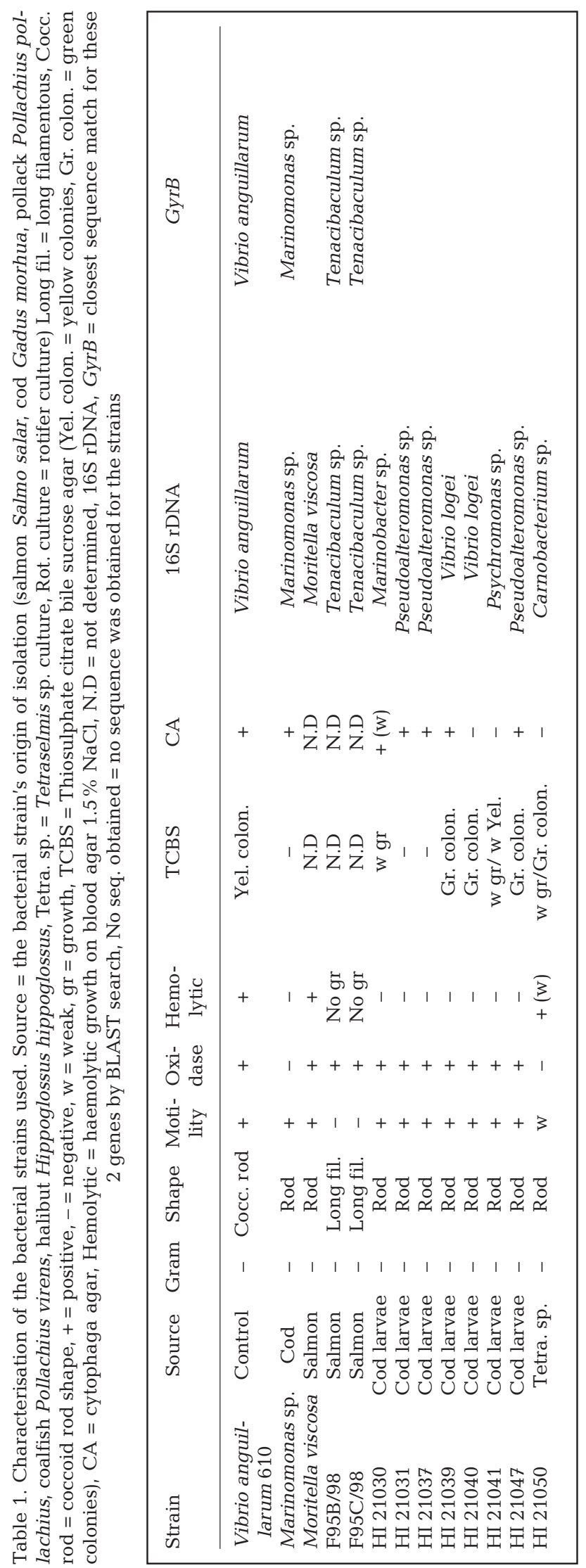




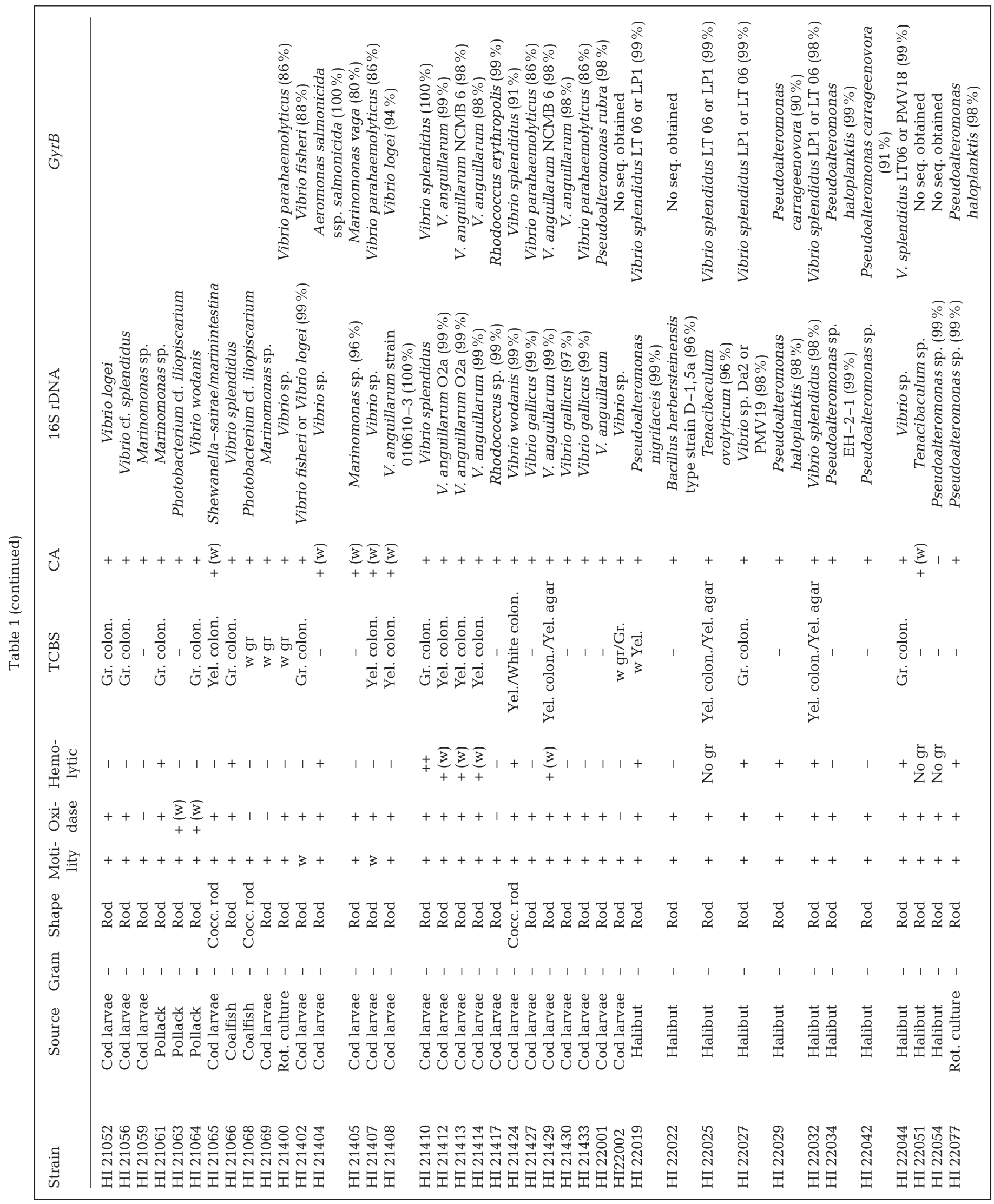




\section{RESULTS}

\section{Bacterial characterisation}

Further characterisation of the bacterial strains used in the challenge experiments showed that all bacterial strains were Gram-negative. Most of the strains were short rod-shaped bacteria except for F95B/98 and F95/C98, which were long filamentous bacteria. These 2 strains were also the only nonmotile strains. Additionally, HI 21050, HI 21402 and HI 21407 proved to be only weakly motile. The majority of the strains were found to be oxidase-positive, except for the strains Marinomonas sp., HI 21050, HI 21059, HI 21068, HI 21069, HI 21017 and HI 22002 (Table 1 shows an overview of all details). In certain cases, the API results were inconclusive (Table 2). HI 21050, which resembled Carnobacterium sp., did not produce any positive results in the API tests. API tests of the strains HI 21412, HI 21413, HI 21414 and HI 21429 revealed similar phenotypic characterisation as is known for other Vibrio anguillarum strains, referring to the ALO test (A: arginine decarboxylase; L: lysine decarboxylase; O: ornithine decarboxylase, ): A+/L-/O- (Alsina \& Blanch 1994) (see Table 2 for more details). This was confirmed by the 16S rDNA and GyrB sequence analysis, which showed 98 to $99 \%$ similarity to various $V$. anguillarum (Table 1) gene sequences. Some of the sequencing analyses produced inconclusive results when the 2 genes were compared. The $16 \mathrm{~S}$ rDNA sequence of HI 21404 showed similarities to Vibrio sp. while the GyrB sequence was $100 \%$ similar to Aeromonas salmonicida subsp. salmonicida. The 16S rDNA sequence for strain HI 21408 was $100 \%$ similar to $V$. anguillarum, while the GyrB sequence was $94 \%$ similar to Vibrio logei. HI 22022 was similar to $V$. anguillarum when the 16S rDNA sequence was BLASTed, but the GyrB sequence showed most similarity to Pseudoalteromonas rubra (98\%). The 16S rDNA and the GyrB sequence of HI 22019 were similar to Pseudoalteromonas nigrificans and Vibrio splendidus, respectively. The last strain to show differences was HI 22025. The $16 \mathrm{~S}$ rDNA sequence was $96 \%$ similar to Tenacibaculum ovolyticum while the GyrB gene sequence was almost identical $(99 \%)$ to $V$. splendidus. The bacterial strain HI 22022 came out as $96 \%$ similar to the Gram-positive bacteria Bacillus herbersteinensis isolated from a medieval wall painting in the chapel of Castle Herberstein, Styria (Austria) (Wieser et al. 2005). Unfortunately, no GyrB gene sequence was obtained for this strain. No GyrB sequences were obtained for HI 22019, HI 22015 and 22054.

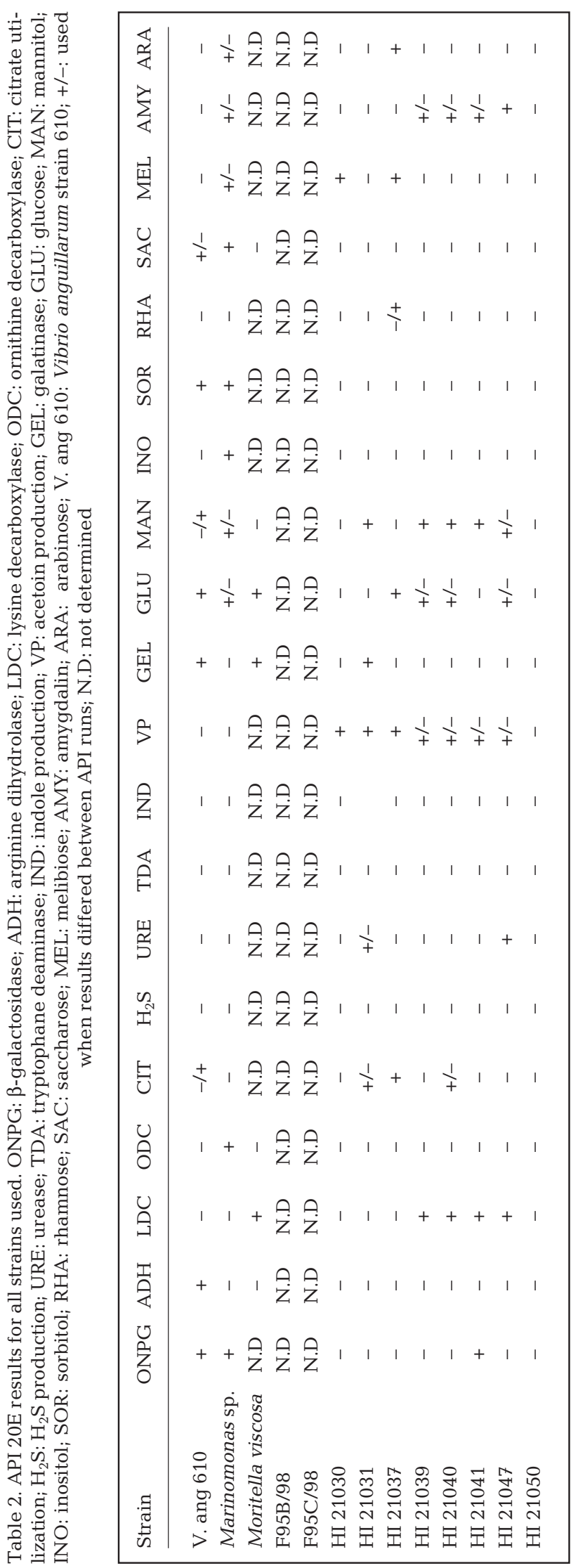




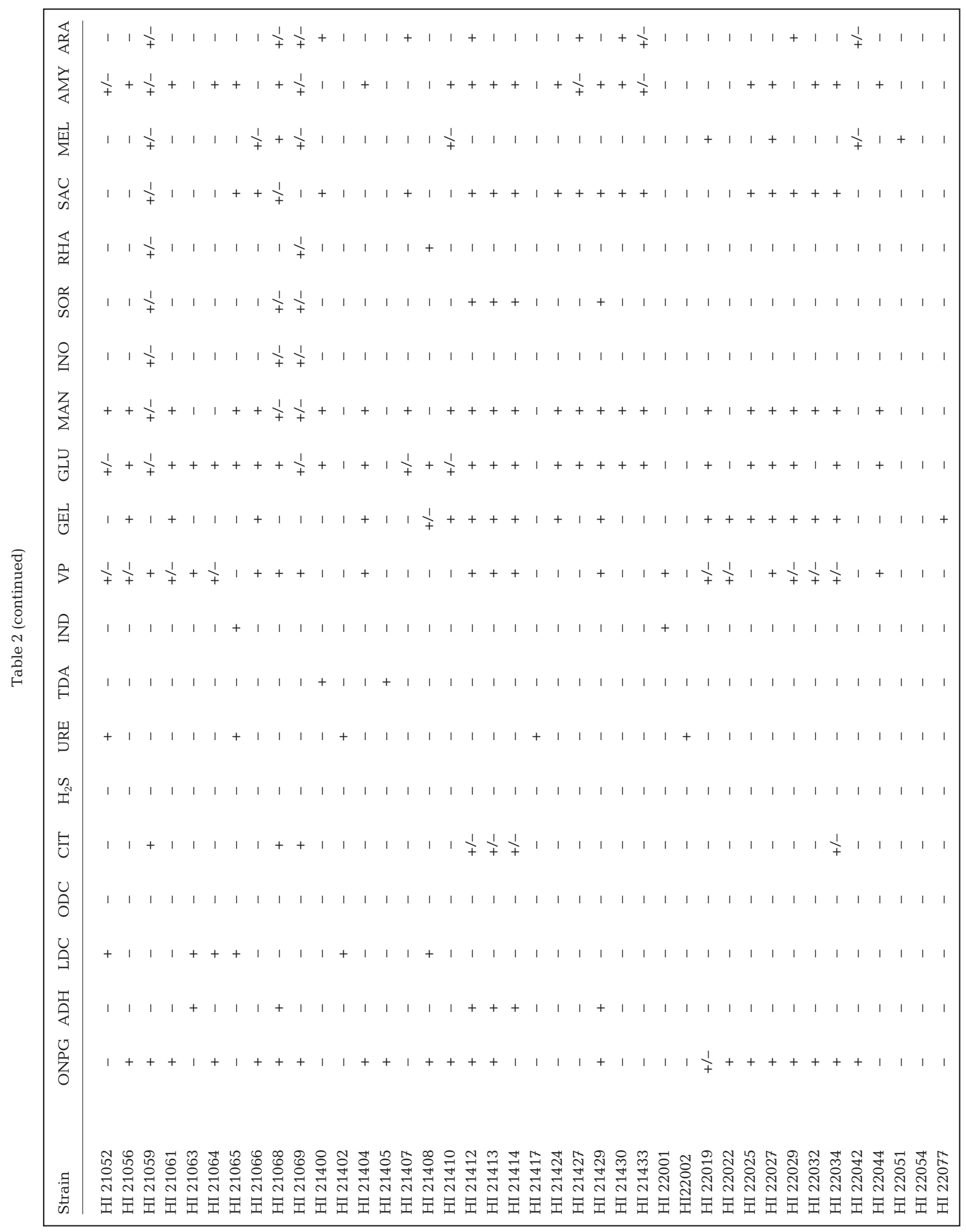



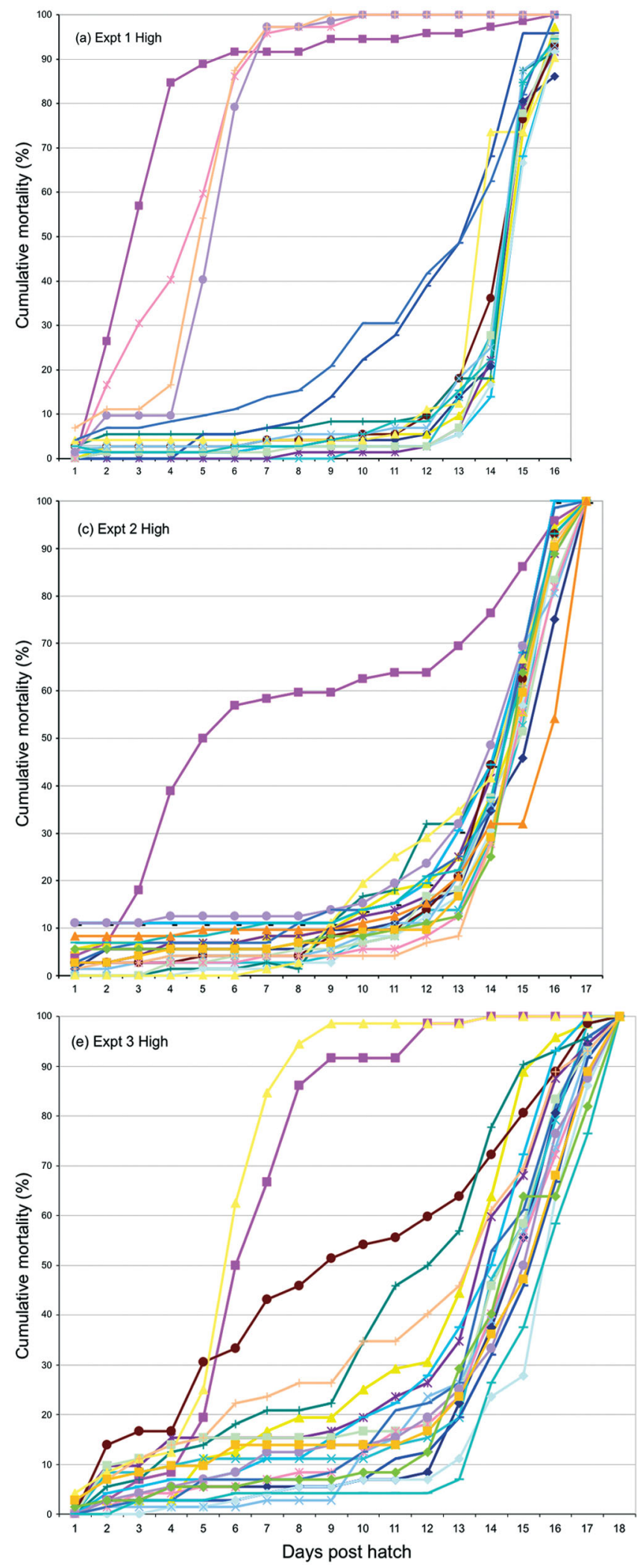
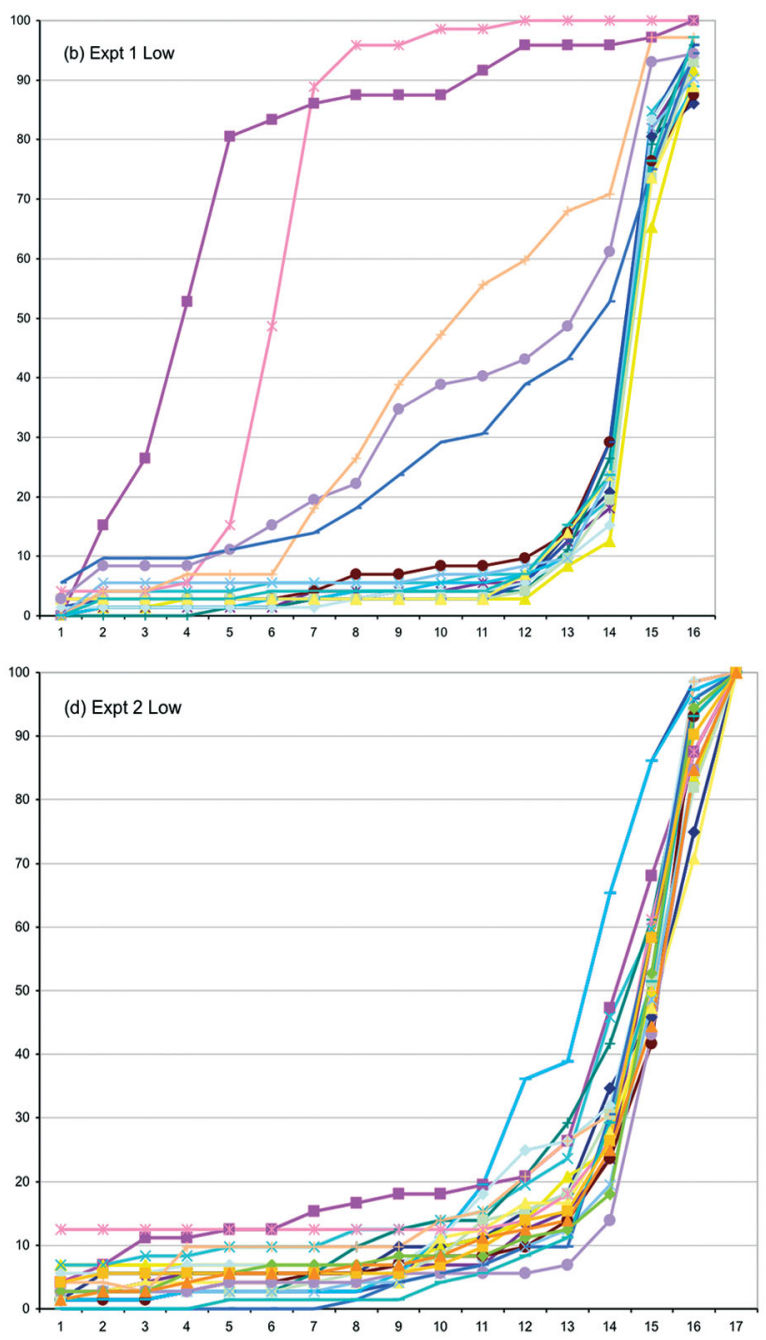

--Positive control

$\longrightarrow$ F95B/98

$\leftarrow$ F95C/98

*-HI 21056

$\rightarrow$ HI 21059

+

- HI 21064

- HI 21066

$\longrightarrow$ HI 21069

$-\mathrm{HI} 21408$

-HI 21410

$\rightarrow-H I 21417$

-HI 21427

$\rightarrow$ HI 21430

$-\mathrm{HI} 21433$

-HI 22029

- HI 22042

$\rightarrow-\mathrm{HI} 22044$

$=-\mathrm{HI} 22054$

-Moritella viscosa

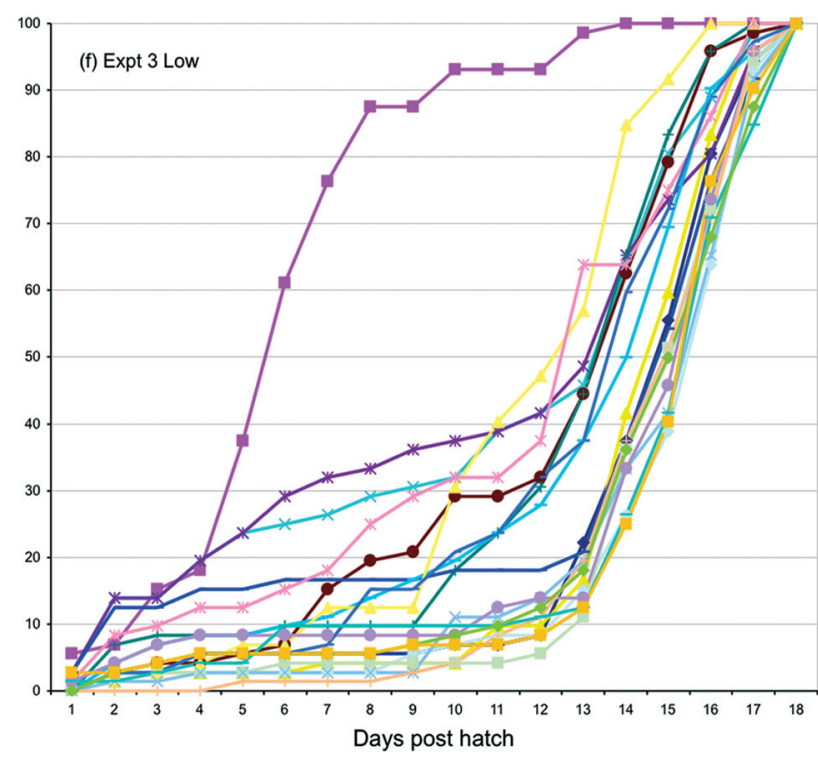

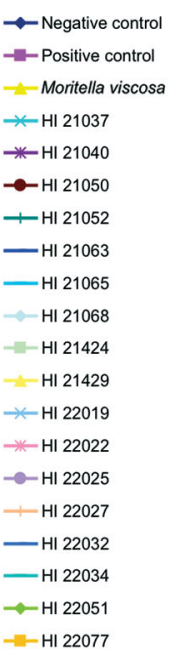

Fig. 1. Gadus morhua. Cumulative mortality (percentages) in (a,b) challenge Expt 1, (c,d) challenge Expt 2, (e,f) challenge Expt 3. Challenge dose is $(\mathrm{a}, \mathrm{c}, \mathrm{e}) 10^{6} \mathrm{CFU} \mathrm{ml}^{-1}$ (high) or (b,d,f) $10^{4} \mathrm{CFU} \mathrm{m}^{-1}$ (low). Negative control is larvae not challenged with bacteria. Positive control is larvae challenged with Vibrio anguillarum strain 610. Remaining names refer to bacterial strains 


\section{Cumulative mortality}

Each of the 3 experiments contained a 'negative' unchallenged control group and 2 'positive' challenged controls (i.e. low- and high-challenge doses. Large differences in survival rates were found between the unchallenged and the challenged control groups (Fig. 1). The differences in mortality rates in the control groups were significantly different throughout all 3 experiments, except for the lowest challenge dose, $10^{4} \mathrm{CFU} \mathrm{ml}^{-1}$, in Expt 2 (Table 3). Mortality rates in the unchallenged control groups were not significantly different from each other except at the end of the experiments on Day 15 ( $p<0.00094$, data not shown).

Only a few of the strains tested caused high mortality rates (significantly different from the negative con- trol groups) early in the experiments (Tables 3,4 \& 5). The increase in mortality observed at the end of the experiments was due to the lack of feeding.

The challenged control groups displayed some differences in terms of when the larvae started to die. In the first experiment the larva tended to die about $4 \mathrm{~d}$ earlier (between Days 3 and 4) than the larvae in Expts 2 and 3 (see Fig. 1). In the second experiment the cumulative mortality among the challenged control group was lower and significantly different $(p<$ 0.00094) from that of the challenged control group in Expts 1 and 3 ( $p<0.00094)$ (Fig. 1). On the other hand, the cumulative mortalities for all other bacterial strains tested in Expt 2 were in the same range as the negative control group (Fig. 1c,d) and not significantly different from each other. However, the Chi-square analysis

Table 3. Yates-corrected Chi-square $\left(\chi^{2}\right)$ values and $p$-values $(p<0.00094$, Bonferroni correction) for individual $2 \times 2$ contingency tables of negative control vs. positive control groups for all 3 challenge experiments. $10^{6}$ and $10^{4}=$ challenge dose $10^{6}$ and $10^{4} \mathrm{CFU} \mathrm{ml}{ }^{-1}$. All significant p-values in bold. Expt $=$ experiment, V. ang $610=$ Vibrio anguillarum strain 610, Day $=$ days post-hatch

\begin{tabular}{|c|c|c|c|c|c|c|c|c|c|c|c|c|}
\hline \multirow[t]{2}{*}{ Expt } & \multirow[t]{2}{*}{ Strain } & \multirow[t]{2}{*}{ Dose } & \multicolumn{2}{|c|}{ — Day 3 - } & \multicolumn{2}{|c|}{ Day $6-$} & \multicolumn{2}{|c|}{ - Day $9-$} & \multicolumn{2}{|c|}{ — Day $12-$} & \multicolumn{2}{|c|}{ — Day $15-$} \\
\hline & & & $\chi^{2}$ & $\mathrm{p}$ & $\chi^{2}$ & $\mathrm{p}$ & $\chi^{2}$ & $\mathrm{p}$ & $\chi^{2}$ & $\mathrm{p}$ & $\chi^{2}$ & $\mathrm{p}$ \\
\hline 1 & V. ang 610 & $10^{6}$ & 51.13 & 0.0000 & 114.33 & 0.0000 & 113.80 & 0.0000 & 113.80 & 0.0000 & 10.72 & 0.0011 \\
\hline 1 & V. ang 610 & $10^{4}$ & 16.78 & 0.0000 & 95.68 & 0.0000 & 97.37 & 0.0000 & 113.80 & 0.0000 & 8.51 & 0.0035 \\
\hline 2 & V. ang 610 & $10^{6}$ & 4.27 & 0.0388 & 41.89 & 0.0000 & 37.53 & 0.0000 & 33.57 & 0.0000 & 24.25 & 0.0000 \\
\hline 2 & V. ang 610 & $10^{4}$ & 0.82 & 0.3657 & 1.35 & 0.2448 & 1.45 & 0.2283 & 0.42 & 0.5157 & 6.37 & 0.0116 \\
\hline 3 & V. ang 610 & $10^{6}$ & 0.60 & 0.4383 & 33.27 & 0.0000 & 103.44 & 0.0000 & 114.33 & 0.0000 & 38.61 & 0.0000 \\
\hline 3 & V. ang 610 & $10^{4}$ & 5.41 & 0.0200 & 47.53 & 0.0000 & 93.90 & 0.0000 & 100.02 & 0.0000 & 38.61 & 0.0000 \\
\hline
\end{tabular}

Table 4. Yates-corrected Chi-square $\left(\chi^{2}\right)$ values and $p$-values $(p<0.00094$, Bonferroni correction) for individual $2 \times 2$ contingency tables of negative control vs. all tested strains in challenge Expt 2 (only challenge dose $10^{6} \mathrm{CFU} \mathrm{ml}^{-1}$ ). All significant $\mathrm{p}$-values in bold. Day = days post-hatch, V. ang $610=$ Vibrio anguillarum strain 610

\begin{tabular}{|c|c|c|c|c|c|c|c|c|c|c|}
\hline \multirow[t]{2}{*}{ Strain } & \multicolumn{2}{|c|}{ — Day 3 - } & \multicolumn{2}{|c|}{ - Day $6-$} & \multicolumn{2}{|c|}{ — Day 9 — } & \multicolumn{2}{|c|}{ — Day 12 - } & \multicolumn{2}{|c|}{ — Day 15 — } \\
\hline & $\chi^{2}$ & $\mathrm{p}$ & $\chi^{2}$ & $\mathrm{p}$ & $\chi^{2}$ & $\mathrm{p}$ & $\chi^{2}$ & $\mathrm{p}$ & $\chi^{2}$ & $\mathrm{p}$ \\
\hline V. ang 610 & 4.27 & 0.0388 & 41.89 & 0.0000 & 37.53 & 0.0000 & 33.57 & 0.0000 & 24.25 & 0.0000 \\
\hline Moritella viscoca & 0.11 & 0.7431 & 0.39 & 0.5304 & 0.08 & 0.7785 & 0.05 & 0.8168 & 2.37 & 0.1239 \\
\hline F95b/98 & 0.00 & 1.0000 & 0.00 & 1.0000 & 0.08 & 0.7785 & 0.19 & 0.6599 & 1.00 & 0.3173 \\
\hline F95c/98 & 0.17 & 0.6767 & 0.17 & 0.6767 & 0.97 & 0.3254 & 0.00 & 1.0000 & 0.44 & 0.5049 \\
\hline HI 21056 & 0.00 & 1.0000 & 0.00 & 1.0000 & 0.08 & 0.7785 & 0.00 & 1.0000 & 4.75 & 0.0293 \\
\hline HI 21059 & 0.17 & 0.6767 & 0.00 & 1.0000 & 0.00 & 1.0000 & 0.00 & 1.0000 & 3.38 & 0.0658 \\
\hline HI 21061 & 2.31 & 0.1282 & 0.83 & 0.3626 & 0.00 & 1.0000 & 4.66 & 0.0309 & 2.79 & 0.0948 \\
\hline HI 21064 & 0.82 & 0.3657 & 0.82 & 0.3657 & 0.00 & 1.0000 & 0.19 & 0.6599 & 6.37 & 0.0116 \\
\hline HI 21066 & 0.82 & 0.3657 & 0.82 & 0.3657 & 0.00 & 1.0000 & 0.19 & 0.6599 & 6.37 & 0.0116 \\
\hline HI 21069 & 2.31 & 0.1282 & 0.83 & 0.3626 & 1.90 & 0.1685 & 0.06 & 0.8096 & 1.36 & 0.2432 \\
\hline HI 21408 & 2.31 & 0.1282 & 0.00 & 1.0000 & 0.39 & 0.5304 & 0.00 & 1.0000 & 0.25 & 0.6169 \\
\hline HI 21410 & 2.31 & 0.1282 & 2.31 & 0.1282 & 0.00 & 1.0000 & 0.00 & 1.0000 & 5.53 & 0.0187 \\
\hline HI 21417 & 0.17 & 0.6767 & 0.00 & 1.0000 & 0.39 & 0.5304 & 0.24 & 0.6224 & 7.28 & 0.0070 \\
\hline HI 21427 & 0.17 & 0.6767 & 0.17 & 0.6767 & 0.97 & 0.3254 & 1.07 & 0.3016 & 1.33 & 0.2482 \\
\hline HI 21430 & 0.82 & 0.3657 & 1.35 & 0.2448 & 0.27 & 0.6055 & 1.11 & 0.2924 & 7.28 & 0.0070 \\
\hline HI 21433 & 0.17 & 0.6767 & 0.00 & 1.0000 & 0.97 & 0.3254 & 1.76 & 0.1849 & 2.79 & 0.0948 \\
\hline HI 22029 & 0.00 & 1.0000 & 0.00 & 1.0000 & 0.27 & 0.6055 & 0.42 & 0.5157 & 6.37 & 0.0116 \\
\hline HI 22042 & 0.00 & 1.0000 & 0.39 & 0.5304 & 0.00 & 1.0000 & 0.42 & 0.5157 & 4.04 & 0.0445 \\
\hline HI 22044 & 0.13 & 0.7160 & 0.13 & 0.7160 & 0.00 & 1.0000 & 0.24 & 0.6224 & 4.04 & 0.0445 \\
\hline HI 22054 & 0.00 & 1.0000 & 0.13 & 0.7160 & 0.09 & 0.7630 & 0.57 & 0.4497 & 2.26 & 0.1330 \\
\hline
\end{tabular}


Table 5. Yates-corrected Chi-square $\left(\chi^{2}\right)$ values and $p$-values $(\mathrm{p}<0.00094$, Bonferroni correction) for individual $2 \times 2$ contingency tables of negative vs. control tested strains. Only strains found to cause mortality significantly different from the negative control are presented in the table. $10^{6}$ and $10^{4}=$ challenge doses $10^{6}$ and $10^{4} \mathrm{CFU} \mathrm{ml}{ }^{-1}$. All significant $\mathrm{p}$-values in bold

\begin{tabular}{|c|c|c|c|c|c|c|c|c|c|c|c|c|}
\hline \multirow[t]{2}{*}{ Expt } & \multirow[t]{2}{*}{ Strain } & \multirow[t]{2}{*}{ Dose } & \multicolumn{2}{|c|}{ - Day $3-$} & \multicolumn{2}{|c|}{ Day 6} & \multicolumn{2}{|c|}{ Day $9-$} & \multicolumn{2}{|c|}{ — Day 12 - } & \multicolumn{2}{|c|}{ — Day $15-$} \\
\hline & & & $\chi^{2}$ & $\mathrm{p}$ & $\chi^{2}$ & $\mathrm{p}$ & $\chi^{2}$ & $\mathrm{p}$ & $\chi^{2}$ & $\mathrm{p}$ & $\chi^{2}$ & $\mathrm{p}$ \\
\hline 1 & HI 21412 & $10^{6}$ & 20.70 & 0.0000 & 101.59 & 0.0000 & 121.02 & 0.0000 & 125.08 & 0.0000 & 13.37 & 0.0003 \\
\hline 1 & HI 21412 & $10^{4}$ & 0.26 & 0.6121 & 40.33 & 0.0000 & 97.37 & 0.0000 & 113.80 & 0.0000 & 8.51 & 0.0035 \\
\hline 1 & HI 21413 & $10^{6}$ & 3.31 & 0.0689 & 87.33 & 0.0000 & 124.79 & 0.0000 & 125.08 & 0.0000 & 13.37 & 0.0003 \\
\hline 1 & HI 21413 & $10^{4}$ & 2.40 & 0.1212 & 7.36 & 0.0067 & 19.55 & 0.0000 & 25.52 & 0.0000 & 3.88 & 0.0489 \\
\hline 1 & HI 21414 & $10^{6}$ & 4.27 & 0.0389 & 104.65 & 0.0000 & 128.67 & 0.0000 & 125.08 & 0.0000 & 13.37 & 0.0003 \\
\hline 1 & HI 21414 & $10^{4}$ & 0.26 & 0.6121 & 1.57 & 0.2109 & 23.68 & 0.0000 & 45.61 & 0.0000 & 8.51 & 0.0035 \\
\hline 1 & HI 21047 & $10^{6}$ & 0.00 & 1.0000 & 0.83 & 0.3626 & 3.04 & 0.0810 & 21.25 & 0.0000 & 6.67 & 0.0098 \\
\hline 1 & HI 21047 & $10^{4}$ & 0.00 & 1.0000 & 0.00 & 1.0000 & 0.00 & 1.0000 & 0.13 & 0.7160 & 0.05 & 0.8285 \\
\hline 1 & HI 22001 & $10^{6}$ & 1.57 & 0.2109 & 1.57 & 0.2095 & 7.68 & 0.0056 & 24.06 & 0.0000 & 0.00 & 0.0000 \\
\hline 1 & HI 22001 & $10^{4}$ & 3.31 & 0.0689 & 5.27 & 0.0218 & 9.81 & 0.0017 & 21.25 & 0.0000 & 0.36 & 0.5476 \\
\hline 3 & HI 21429 & $10^{6}$ & 2.69 & 0.1012 & 49.50 & 0.0000 & 121.21 & 0.0000 & 114.33 & 0.0000 & 38.61 & 0.0000 \\
\hline 3 & HI 21429 & $10^{4}$ & 0.26 & 0.6121 & 0.00 & 1.0000 & 1.35 & 0.2448 & 25.23 & 0.0000 & 22.34 & 0.0000 \\
\hline 3 & HI 21050 & $10^{6}$ & 6.41 & 0.0114 & 16.00 & 0.0001 & 34.92 & 0.0000 & 40.09 & 0.0000 & 9.23 & 0.0024 \\
\hline 3 & HI 21050 & $10^{4}$ & 0.00 & 1.0000 & 0.00 & 1.0000 & 6.06 & 0.0138 & 11.05 & 0.0009 & 8.09 & 0.0045 \\
\hline 3 & HI 21052 & $10^{6}$ & 0.60 & 0.4383 & 4.27 & 0.0388 & 7.03 & 0.0080 & 28.27 & 0.0000 & 20.25 & 0.0000 \\
\hline 3 & HI 21052 & $10^{4}$ & 1.19 & 0.2751 & 0.39 & 0.5304 & 0.39 & 0.5304 & 9.98 & 0.0016 & 11.81 & 0.0006 \\
\hline 3 & HI 22027 & $10^{6}$ & 2.69 & 0.1012 & 7.03 & 0.0080 & 10.14 & 0.0015 & 18.27 & 0.0000 & 2.40 & 0.1213 \\
\hline 3 & HI 22027 & $10^{4}$ & 0.51 & 0.4764 & 0.83 & 0.3626 & 0.17 & 0.6767 & 0.08 & 0.7785 & 0.11 & 0.7383 \\
\hline
\end{tabular}

confirmed that mortality rates of the high-dose challenged controls and the unchallenged control group were significantly different from each other (Table 4). The mortality rates of the positive controls in Expts 1 and 3 were not found to be significantly different (data not shown).

As Fig. 1a,b,e,f shows, only the 5 strains HI 21412, HI 21413, HI 21414, HI 21429 and HI 21050 caused high mortality. Of these 5 strains, HI 21412 appeared to be the most virulent. Mortality caused by this strain was significantly different from the mortality rate found in the negative control group on Day 3 post-hatch (challenge dose $10^{6} \mathrm{CFU} \mathrm{ml}^{-1}$ ) and on Day 6 (challenge dose $10^{4} \mathrm{CFU} \mathrm{m}{ }^{-1}$ ). The mortality rates for the remaining 4 strains were found to be significantly different from that of the unchallenged control group from Day 6 onwards for the high-challenge dose and from Day 9 in the low-challenge dose group ( $p<0.00094$, Table 5). The low-challenge dose did not cause any increase in mortality rate in larval groups challenged with HI 21050. Compared to the positive control, these strains did not produce significantly different results. Strains HI 21052, HI 22001 and HI 22027, resembling Vibrio logei, V. anguillarum and V. splendidus, respectively, (see Table 1) led to cumulative mortality rates that were different from challenged control groups (Fig. 1a,b,e,f). However, the mortality rates for these strains were significantly different from the unchallenged control group ( $p<0.00094$, Table 5) only at the end of the experiment (i.e. from Day 12 on- wards), indicating that they had a longer incubation period. The same strains were also significantly different from the positive control, indicating they are less virulent (data not shown). It should be noted that the low-challenge dose of these 3 strains did not appear to cause the same increase in mortality as was found in the high-challenge dose groups.

Cumulative mortality rates in the remaining 45 strains (see Fig. 1) did not differ significantly from the negative control groups ( $p>0.00094$, data not shown). The mortality rates for the same groups were, however, found to be significantly different from the positive control group ( $\mathrm{p}<0.00094$, data not shown). This indicates that these 45 strains had no harmful effect on mortality rates.

\section{Immunostaining of bacterial smears and Mono-Va testing}

The 4 pathogenic strains HI 21412, HI 21413, HI 21414 and HI 21429, which were found to have similar 16S rDNA and GyrB sequences as Vibrio anguillarum, were tested for positive immunostaining with 3 different antisera against the $V$. anguillarum serotypes $\mathrm{O} 2 \alpha, \mathrm{O} 2 \beta$ and O1. Positive immunostaining was only found when they were stained with the antiserum against the $\mathrm{O} 2 \alpha$ serotype. On the other hand, when tested with the Mono-Va agglutination kit for $V$. anguillarum strains, no positive reaction was found in any of the 4 strains. 


\section{DISCUSSION}

The aim of this study was to evaluate the virulence of candidate pathogenic bacteria among bacterial isolates associated with diseased cod larvae, other marine cold-water fish and live fish cultures. Out of 53 bacterial strains tested, only the 5 strains HI 21412, HI 21413, HI 21414, HI 21429 and HI 21050 could be classified as primary pathogens, i.e. had a negative effect on cod larva survival. This indicated that most of the bacteria associated with and isolated from moribund cod Gadus morhua larvae, halibut Hippoglossus hippoglossus, coalfish Pollachius virens and pollack Pollachius pollachius, are not primary pathogens, i.e. they are probably not primary causes of disease. Similar results were found by Verner-Jeffreys et al. (2003) when testing virulence among bacterial strains isolated from halibut hatcheries.

Four strains in this high mortality group were shown to resemble Vibrio anguillarum by $16 \mathrm{~S}$ rDNA and GyrB analyses. This confirms that vibriosis may also be a problem in the aquaculture of early life stages of cod. However, serotyping of these 4 strains, HI 21412, HI 21413, HI 21414 and HI 21429, did not provide any clear results. Serological testing with specific antisera against the $V$. anguillarum serotypes, $\mathrm{O} 1, \mathrm{O} 2 \alpha$ and $\mathrm{O} 2 \beta$, produced positive results only against the $\mathrm{O} 2 \alpha$ serum. At the same time, no positive results were found by using a Mono-Va agglutination kit, which should have produced positive results for the O1, O2 and $\mathrm{O} 3$ serotypes. This can be explained by the possibility that these $V$. anguilllarum strains differ from serotypes known today, for which commercially produced antisera exist. A recent study by Mikkelsen et al. (2007) showed that bacteria isolated from diseased cod differ from $\mathrm{O} 2 \alpha$ and $\mathrm{O} 2 \beta$ isolates serologically, biochemically and genotypically. These authors further indicate that these $V$. anguillarum isolates belong to a new sero-subtype. However, the 4 isolates used in the present study are biochemically and genotypically consistent with $V$. anguillarum. The ALO test gave $\mathrm{A}+/ \mathrm{L}-/ \mathrm{O}-$ as a classification of the $V$. anguillarum strains (see Table 2). However, further studies are needed to compare already known isolates and serotypes with these findings. Studies of this kind are probably essential if efficient vaccines are to be developed. Vaccines developed for cod do not provide sufficient protection; vibriosis is still a problem in cod farming even though vaccines for cod have been on the market for more than $10 \mathrm{yr}$ (Samuelsen et al. 2006).

Strain HI 21050, resembling Carnobacterium sp., was isolated from a culture of the alga Tetraselmis sp. This alga is commonly used as a feed and enrichment in rotifer cultures (Muller-Feuga et al. 2003). Algal cultures are associated with bacterial populations. Popu- lation studies of algal cultures used as feed for scallop larvae have identified a variety of bacterial strains associated with the algal cultures (Sandaa et al. 2003, Nicolas et al. 2004), probably including opportunistic pathogens as well as commensal or mutualistic bacteria. In intensive aquaculture, cod larvae are offered rotifers, usually Brachionus plicatilis, and brine shrimp, mostly Artemia franciscana, as live feed (Svåsand et al. 2004, Reitan 2005). Recently, Korsnes et al. (2006) demonstrated the presence of bacteria with high sequence similarity to Vibrio anguillarum in rotifer cultures and the gut of cod larvae fed rotifers. Both rotifers and Artemia sp. are filter feeders capable of concentrating large amounts of bacteria, and live feed is a major source of bacterial influx to the gastrointestinal tract of fish (Nicolas et al. 1989, Skjermo \& Vadstein 1993, Makridis et al. 2000a,b). The present results support the view that the composition of this influx influences larval survival. However, as most strains did not induce mortality, they could be viewed as secondary pathogens, i.e. opportunists that invade already stressed or weakened larvae.

Three strains, HI 21052, HI 22001 and HI 22027, resembling Vibrio logei, V. anguillarum and V. splendidus, respectively, caused mortality rates that were significantly different from the negative control from Day 9 post-hatching. These strains appeared to have a slower infection rate that could have been caused by non-optimal growth conditions for the specific bacterium, such as temperature, salinity and nutrients. Therefore, it cannot be ruled out that these bacterial strains might act like primary pathogens under different growth conditions. During laboratory studies fish are kept under controlled optimal conditions, which might make them more capable of dealing with an infection compared to fish kept in commercial farms. The bacterial strain HI 22001 is probably a less virulent strain of $V$. anguillarum. Differences in virulence among $\mathrm{O} 1$ isolates of $V$. anguillarum were reported by Pedersen et al. (1997), and it is likely that differences in virulence will occur among all $V$. anguillarum serotypes. Less virulent $\mathrm{O} 2$ strains of $V$. anguillarum, isolated from cod, have also been reported (Mikkelsen et al. 2007).

None of the 3 different Vibrio logei strains tested had any negative effect on larval survival. This was not expected prior to the challenge experiments. V. logei is frequently isolated from moribund and dead larvae and it has been assumed to play a significant role in bacterial problems experienced in hatcheries. There are several possible explanations to why bathchallenge did not have any effect. A challenge dose of $10^{6} \mathrm{CFU} \mathrm{m} \mathrm{m}^{-1}$ may not be sufficient to cause disease. It is possible to grow $V$. logei in cultures up to $10^{8} \mathrm{CFU}$ $\mathrm{ml}^{-1}(\varnothing$. Bergh pers. obs.), so a higher challenge dose 
should be tested in repeated experiments. Additionally, cod larvae drink water from hatching onwards (Mangor-Jensen \& Adoff 1987), thus bacteria will enter the gastrointestinal tract. Consequently, the intestine as a route of entry for pathogenic bacteria cannot be ruled out. Our results suggest that a route of entry other than bath-challenge alone is required or, alternatively, that a combination of both bath and oral exposure is needed. Experiments that deliver challenges via live feed have been performed on turbot Scophthalmus maximus larvae (Grisez et al. 1996, Planas et al. 2005) but to the best of our knowledge no such experiments have been performed on cod larvae. Another explanation for the lack of pathogenicity is the possibility of quorum sensing. $V$. logei strains were first described as symbiotic with Vibrio fisheri in squid (Sepiola robusta and Sepiola affinis) light organs (Fidopiastis et al. 1998). The 2 luminous bacteria are closely related, and with $V$. logei being symbiotic with a bacterium capable of quorum sensing (Dunlap 1999, Milton 2006), it is reasonable to believe that $V$. logei might possess some of the same abilities as its fellow organism. This leaves room for speculation about whether or not $V$. logei is an opportunist taking advantage of other bacteria, perhaps through mechanisms of quorum sensing. The work done by Fidopiastis et al. (1998) also confirms the difficulty of distinguishing 2 closely related coexisting bacteria by growth and genetic analyses. During a disease outbreak, finding and isolating the primary pathogen could thus be difficult if other agents are present at high densities, as $V$. logei often is. The role of $V$. logei in disease outbreaks in cod hatcheries still needs to be elucidated.

Moritella viscosa has been isolated from cultivated cod that display skin lesions similar to the ones seen on salmonids (Colquhoun et al. 2004), but the bacteria showed some phenotypical differences from the NCIMB $13584^{\mathrm{T}}$ strain. The M. viscosa isolate used in these experiments did not have any negative effect on cod larvae. In a study performed by Gudmundsdóttir et al. (2006), a bath challenge with $M$. viscosa resulted in mortality only when the challenge dose was as high as $10^{7} \mathrm{CFU} \mathrm{ml}^{-1}$. Similar results were obtained by Björnsdóttir et al. (2004), in challenge experiments on turbot juveniles $(50 \mathrm{~g})$. No clinical signs were found on fish challenged with the lowest dose $\left(10^{6} \mathrm{CFU} \mathrm{m}{ }^{-1}\right)$ in either of these 2 experiments. On this basis, future experiments on cod larvae should include a higher challenge dose. However, in the present experiments we chose to use the same challenge dose for all strains tested. A challenge dose of $10^{6} \mathrm{CFU} \mathrm{ml}^{-1}$ is frequently used in challenge experiments and is generally considered to be a high challenge dose (Bergh et al. 1992, Vik-Mo et al. 2005, Sandlund et al. 2006, Schrøder et al. 2006).
When comparing growth temperatures, Tunsjø et al. (2007) found that Moritella viscosa grew denser and had better motility at $4^{\circ} \mathrm{C}$ and with the addition of 3 to $4 \% \mathrm{NaCl}$, than at $15^{\circ} \mathrm{C}$ with $1 \% \mathrm{NaCl}$. Conditions for growth in the present experiments should be within the range of optimal growth for this bacterium. The same temperature was used both to grow the bacterial cultures and as the incubation temperature inside the air-conditioned room. This was done to keep conditions as close to the natural environment as possible, where the bacteria grow under the same conditions as the larvae. Changes in characteristics when bacterial strains have been grown at different temperatures have been observed ( $\varnothing$. Bergh pers. obs).

The reason for the differences seen between the challenged control groups, especially in Expt 2, is not known. It could have been caused by inaccuracy when the dilutions of these particular bacterial suspensions were made. It is known that loss of flagella, for example during the washing procedure, makes the bacterium less pathogenic, as the flagella are very important as a source of virulence (Milton et al. 1996, O'Toole et al. 1996). Before challenge, all bacterial suspensions were examined to verify that the motile bacteria were still intact and motile after the washing procedure. Hence it is unlikely that the loss of flagella was the cause of differences in mortality. Reduction or loss of virulence induced by washing of bacterial suspensions should also be considered. However, given that all bacterial suspensions were grown under the same conditions and that this washing procedure is routinely used in our laboratory this is unlikely to have affected the results.

To keep unfed cod larvae alive for up to $14 \mathrm{~d}$ posthatch shows that the multi-dish system is well adapted for studying bath challenge for cod larvae as well as for halibut (Bergh et al. 1992, 1997), turbot (Bergh et al. 1997, Hjelm et al. 2004) and great scallop larvae (Sandlund et al. 2006). Only at the end of the experiments, $15 \mathrm{~d}$ post-hatching were significant differences found between the unchallenged control groups in the 3 experiments. These differences might be caused by differences in the yolk-sac content among different larval groups.

To obtain a complete starvation induced mortality curve the larvae were kept alive until death by starvation. This was done to avoid losing important data, which has occurred in previous cod yolk-sac larvae experiments. To the best of our knowledge this is the first study to carry out such experiments on cod larvae. Furthermore, all 3 experiments were performed identically, which ensures the results are reliable. Similar future experiments using similar conditions can now be brought to an end at an earlier stage.

None of the bacterial strains were re-isolated from the larvae. Larvae possess a sterile digestive system 
until hatching, when it is colonized by the egg flora (reviewed by Vine et al. 2006). Reisolation of bacteria from larvae is difficult, particularly due to the small size of the larvae; the need for exterior washing or disinfection results in a decreased number of viable bacteria. Concerning this matter we chose immunochemistry methods to verify the presence of Vibrio anguillarum (Engelsen et al. 2008). Given that sterile water and a high concentration of bacteria were added to each well, it is reasonable to believe that the dominant bacteria inside the wells were the bacteria used for challenge. Furthermore, the eggs were selected at random and most of the larvae lived until the point of starvation, indicating that the larvae did not die of factors other than the bacterial strains added.

The use of API 20E as a diagnostic tool for aquatic bacteria has been debated for decades, as reviewed by Popovic et al. (2007). According to Alsina \& Blanch (1994), this could be a useful tool when adjustments or modifications to the manufacturer manual are being made and as a supplement to other methods of identification. In our laboratory we modified the API protocol to suit cold-water bacterial strains on the basis of previous experience. In spite of this we observed some inconclusive results among some of the bacterial strains tested, especially concerning the fermentation of sugars. This has occasionally been observed in our laboratory (authors' pers. obs.).

Analyses of $16 \mathrm{~S}$ rDNA and $G y r B$ gene sequences were primarily used as a preliminary stage of identification to limit the number of bacteria used in these challenge trials and for further characterisation. When the $16 \mathrm{~S}$ rDNA and GyrB sequences were compared, some identifications were inconclusive (see Table 1). This may have been due to polymorphism and heterogeneity in the 16S rDNA gene (Dahllöf et al. 2000, Moreno et al. 2002), which would make it difficult to identify strains based on 1 gene only. Several other genes have been suggested as additional sources of information for identifying bacterial strains, for instance recA (Thompson et al. 2004b), rpoB (Dahllöf et al. 2000), GyrB, fusA, and nifD (Holmes et al. 2004). Another aspect is the limited number of $\operatorname{GyrB}$ sequences available in the GeneBank compared to $16 \mathrm{~S}$ rDNA sequences. This is probably the cause of the low frequency of matches with GyrB found in the database. The average length of the fragments used in this study is in the range of 1250 to 1350 nucleotides for the $16 \mathrm{~S}$ rDNA gene and 1100 to 1200 nucleotides for the GyrB gene, which is normally sufficient to obtain a match.

Acknowledgements. This work was funded by the Norwegian Research Council (Project No 158882/110). We thank E. Karlsbakk, H. Mikkelsen and A. B. Olsen for providing the bacterial strains HI 21030-HI 21069, Moritella viscosa and
F95B/98 and F95C/98, respectively. Special thanks to Erling Otterlei (Sagafjord Sea Farm AS) for providing the cod eggs, K. Korsnes, I. Wangen, L. Sandlund, R. H. Olsen, I. R. Sunde, L. Brunvold, E. Karlsbakk, Kirsten Bottolfsen and J. Aseerwatham for spending long cold hours dividing cod eggs into the Nunc trays and K. Glover for comments and useful advice with the statistics.

\section{LITERATURE CITED}

Alsina M, Blanch AR (1994) A set of keys for biochemicalidentification of environmental vibrio species. J Appl Bacteriol 76:79-85

Altschul SF, Gish W, Miller W, Myers EW, Lipman DJ (1990) Basic local alignment search tool. J Mol Biol 215:403-410

Bergh Ø, Hansen GT, Taxt RE (1992) Experimental infection of eggs and yolk sac larvae of halibut, Hippoglossus hippoglossus L. J Fish Dis 15:379-391

Bergh Ø, Hjeltnes B, Skiftesvik AB (1997) Experimental infection of turbot Scophthalmus maximus and halibut Hippoglossus hippoglossus yolk sac larvae with Aeromonas salmonicida subsp. salmonicida. Dis Aquat Org 29:13-20

Björnsdóttir B, Gudmundsdottir S, Bambir SH, Magnadóttir B, Gudmundsdóttir BK (2004) Experimental infection of turbot, Scophthalmus maximus (L.), by Moritella viscosa, vaccination effort and vaccine-induced side-effects. J Fish Dis 27:645-655

Brunvold L, Sandaa RA, Mikkelsen H, Welde E, Bleie H, Bergh $\varnothing ~(2007)$ Characterisation of bacterial communities associated with early stages of intensively reared cod (Gadus morhua) using denaturing gel gradient electrophoresis. Aquaculture 272:319-327

Colquhoun DJ, Hovland H, Hellberg H, Haug T, Nilsen H (2004) Moritella viscosa isolated from farmed Atlantic cod (Gadus morhua). Bull Eur Assoc Fish Pathol 24:109-114

Dahllöf I, Baillie H, Kjelleberg S (2000) rpoB-based microbial community analysis avoids limitations inherent in $16 \mathrm{~S}$ rDNA gene intraspecies heterogeneity. Appl Environ Microbiol 66:3376-3380

> Dunlap PV (1999) Quorumsensing regulation of luminescence in Vibrio fisheri. J Mol Microbiol Biotechnol 1:5-12

Engelsen AR, Sandlund N, Fiksdal IU, Bergh Ø (2008) Immunohistochemistry of Atlantic cod larvae Gadus morhua experimentally challenged with Vibrio anguillarum. Dis Aquat Org 80:13-20

Fidopiastis PM, von Boletzky S, Ruby EG (1998) A new niche for Vibrio logei, the predominant light organ symbiont of squids in the genus Sepiola. J Bacteriol 180:59-64

Grisez L, Chair M, Sorgeloos P, Ollevier F (1996) Mode of infection and spread of Vibrio anguillarum in turbot Scophthalmus maximus larvae after oral challenge through live feed. Dis Aquat Org 26:181-187

Gudmundsdóttir BK, Björnsdòttir B, Gudmundsdóttir S, Bambir SH (2006) A comparative study of susceptibility and induced pathology of cod, Gadus morhua (L.), and halibut, Hippoglossus hippoglossus (L.), following experimental infection with Moritella viscosa. J Fish Dis 29: 481-487

> Hagström Å, Pinhassi J, Zweifel UL (2000) Biogeographical diversity among marine bacterioplankton. Aquat Microb Ecol 21:231-244

Hagström ̊̊, Pommier T, Rohwer F, Simu K, Stolte W, Svensson D, Zweifel UL (2002) Use of 16S ribosomal DNA for delineation of marine bacterioplankton species. Appl Environ Microbiol 68:3628-3633

> Hansen GH, Olafsen JA (1989) Bacterial colonization of cod (Gadus morhua L.) and halibut (Hippoglossus hippoglos- 
sus) eggs in marine aquaculture. Appl Environ Microbiol 55:1435-1446

Hjelm M, Bergh O, Riaza A, Nielsen J and others (2004) Selection and identification of autochthonous potential probiotic bacteria from turbot larvae (Scophthalmus maximus) rearing units. Syst Appl Microbiol 27:360-371

$>$ Holmes DE, Nevin KP, Lovley DR (2004) Comparison of 16S rRNA, nifD, recA, gyrB, rpoB and fusA genes within the family Geobacteraceae fam. nov. Int J Syst Evol Microbiol 54:1591-1599

Knappskog DH, Rødseth OM, Slinde E, Endresen C (1993) Immunochemical analyses of Vibrio anguillarum strains isolated from cod, Gadus morhua L., suffering from vibriosis. J Fish Dis 16:327-338

Kongsvik R (2007) Produksjon av torsk og kveite i 2006. The production of cod and halibut in 2006. In: Dahl E, Hansen PK, Haug T, Karlsen Ø (eds) Fisken og havet særnummer 2. Institute of Marine Research, Bergen, p 114-117 (in Norwegian with an English summary)

Korsnes K, Nicolaisen O, Skår C, Nerland AH, Bergh Ø (2006) Bacteria in the gut of juvenile cod (Gadus morhua) fed live feed enriched with four different commercial diets. J Mar Sci 63:296-301

Makridis P, Fjellheim AJ, Skjermo J, Vadstein O (2000a) Control of the bacterial flora of Brachionus plicatilis and Artemia franciscana by incubation in bacterial suspensions. Aquaculture 185:207-218

Makridis P, Fjellheim AJ, Skjermo J, Vadstein O (2000b) Colonization of the gut in first feeding turbot by bacterial strains added to the water or bioencapsulated in rotifers. Aquacult Int 8:367-380

> Mangor-Jensen A, Adoff GR (1987) Drinking activity of the newly hatched larvae of cod Gadus morhua L. Fish Physiol Biochem 3:99-103

Mikkelsen H, Lund V, Martinsen LC, Gravingen K, Schrøder MB (2007) Variability among Vibrio anguillarum O2 isolates from Atlantic cod (Gadus morhua L.): characterisation and vaccination studies. Aquaculture 266:16-25

> Milton DL (2006) Quorum sensing in vibrios: complexity for diversification. Int J Med Microbiol 296:61-71

> Milton DL, O'Toole R, Horstedt P, Wolf-Watz H (1996) Flagellin $\mathrm{A}$ is essential for the virulence of Vibrio anguillarum. J Bacteriol 178:1310-1319

Moreno C, Romero J, Espejo RT (2002) Polymorphism in repeated 16S rDNA genes is a common property of type strains and environmental isolates of the genus Vibrio. Microbiology 148:1233-1239

Muller-Feuga A, Moal J, Kaas R 2003. The microalgae of aquaculture. In: Støttrup J, McEvoy L (eds) Live feeds in marine aquaculture. Blackwell Science, Oxford, p 206-252

> Nicolas JL, Robic E, Ansquer D (1989) Bacterial-flora associated with a trophic chain consisting of microalgae, rotifers and turbot larvae-influence of bacteria on larval survival. Aquaculture 83:237-248

> Nicolas JL, Corre S, Cochard JC (2004) Bacterial population association with phytoplankton cultured in a bivalve hatchery. Microb Ecol 48:400-413

> Oeding P (1957) Agglutinability of pyrogenic Staphylococci at various conditions. Acta Pathol Microbiol Scand 41: $310-324$

> Olafsen JA (2001) Interactions between fish larvae and bacteria in marine aquaculture. Aquaculture 200:223-247

> Olafsen JA, Hansen GH (1992) Intact antigen uptake in intestinal epithelial cells of marine fish larvae. J Fish Biol 40:141-156

O'Toole R, Milton DL, Wolf-Watz H (1996) Chemotactic motility is required for invasion of the host by the fish pathogen Vibrio anguillarum. Mol Microbiol 19:625-637

Pedersen K, Gram L, Austin DA, Austin B (1997) Pathogenicity of Vibrio anguillarum serotype O1 strains compared to plasmids, outer membrane protein profiles and siderophore production. J Appl Microbiol 82:365-371

> Planas M, Pérez-Lorenzo M, Vázquez JA, Pintado J (2005) A model for experimental infections with Vibrio (Listonella) anguillarum in first feeding turbot (Scophthalmus maximus L.) larvae under hatching conditions. Aquaculture 250:232-243

Popovic N, Coz-Rakovac R, Stunjak-Perovic I (2007) Commercial phenotypic tests (API 20E) in diagnosis of fish bacteria: a review. Vet Med 52:49-53

Reitan KI (2005) Produksjon av levende fôr. In: Otterå H, Taranger GL, Borthen J (eds) Oppdrett av torsk-næring i framti. Norsk Fiske Oppdrett AS, Fragernes, p 121-142

> Rice WR (1989) Analyzing tables of statistical tests. Evolution 43:223-225

> Samuelsen OB, Bergh $\varnothing$ (2004) Efficacy of orally administrated florfenicol and oxolinic acid for the treatment of vibriosis in cod (Gadus morhua). Aquaculture 235:27-35

- Samuelsen OB, Lunestad BT, Jelmert A (1997) Pharmacokinetic and efficacy studies on bath-administering potentiated sulphonamides in Atlantic halibut, Hippoglossus hippoglossus L. J Fish Dis 20:287-296

> Samuelsen OB, Nerland AH, Jørgensen T, Schrøder MB, Svåsand T, Bergh Ø (2006) Viral and bacterial diseases of Atlantic cod Gadus morhua, their prophylaxis and treatment: a review. Dis Aquat Org 71:239-254

> Sandaa RA, Magnesen T, Torkildsen L, Bergh Ø (2003) Characterisation of the bacterial community associated with early stages of great scallop (Pecten maximus), using denaturing gradient gel electrophoresis (DGGE). Syst Appl Microbiol 26:302-311

> Sandlund N, Torkildsen L, Magnesen T, Mortensen S, Bergh $\varnothing$ (2006) Immunohistochemistry of great scallop Pecten maximus larvae experimentally challenged with pathogenic bacteria. Dis Aquat Org 69:163-173

Schrøder MB, Mikkelsen H, Børdal S, Gravningen K, Lund V (2006) early vaccination and protection of Atlantic cod (Gadus morhua L.) juveniles against classical vibriosis. Aquaculture 254:46-53

Seljestokken B, Bergh $\varnothing$, Melingen GO, Rudra H, Hetlelid Olsen R, Samuelsen OB (2006) Treating experimentally induced vibriosis (Listonella anguillarum) in cod, Gadus morhua L., with florfenicol. J Fish Dis 29:737-242

Skjermo J, Vadstein O (1993) Characterization of the bacterial-flora of mass cultivated Brachionus-Plicatilis. Hydrobiologia 255-256:185-191

Spangaard B, Huber I, Nielsen J, Nielsen T, Gram L (2000) Proliferation and location of Vibrio anguillarum during infection of rainbow trout, Oncorhynchus mykiss (Walbaum). J Fish Dis 23:423-427

Svåsand T, Otterå HM, Taranger GL, Litvak M and others (2004) The status and perspectives for the species. In: Moksness E, Kjørsvik E, Olsen Y (eds) Culture of coldwater marine fish. Blackwell Publishing, Oxford, p 433-474

Thompson FL, Iida T, Swings J (2004a) Biodiversity of vibrios. Microbiol Mol Biol Rev 68:403-431

> Thompson CC, Thompson FL, Vandemeulebroecke K, Hoste B, Dawyndt P, Swings J (2004b) Use of recA as an alternative phylogenetic marker in the family Vibrionaceae. Int J Syst Evol Microbiol 54:919-924

Toranzo AE, Magarinos B, Romalde JL (2005) A review of the main bacterial fish diseases in mariculture systems. Aquaculture 246:37-61 
Tunsjø HS, Paulsen SM, Mikkelsen H, L'Abée-Lund TM, Skjerve E, Sørum H (2007) Adaptive response to environmental changes in the fish pathogen Moritella viscosa. Res Microbiol 158:244-250

Vadstein O, Mo TA, Bergh Ø (2004) Microbial interactions, Prophylaxis and diseases. In: Moksness E, Kjørsvik E, Olsen Y (eds) Culture of cold-water marine fish. Blackwell Publishing, Oxford, p 28-72

$>$ Verner-Jeffreys DW, Shields RJ, Birkbeck TH (2003) Bacterial influences on Atlantic halibut Hippoglossus hippoglossus yolk-sac larval survival and start-feed response. Dis Aquat Org 56:105-113

Vik-Mo FT, Bergh Ø, Samuelsen OB (2005) Efficacy of orally administered flumequine in the treatment of vibriosis caused by Listonella anguillarum in Atlantic cod Gadus

Editorial responsibility: Robin Overstreet,

Ocean Springs, Mississippi, USA morhua. Dis Aquat Org 67:87-92

Vine NG, Leukes WD, Kaiser H (2006) Probiotics in marine larviculture. FEMS Microbiol Rev 30:404-427

Whitman KA (2004) Bacteriology culture media. In: Whitman KA with contributions by MacNair NG (ed) Finfish and shellfish bacteriology manual, techniques and procedures. Blackwell Publishing Company, Iowa State Press, Ames, IA, p 81-106

Wieser M, Worliczek H, Kämpfer P, Busse HJ (2005) Bacillus herbersteinensis sp. nov. Int J Syst Evol Microbiol 55: $2119-2123$

Yamamoto S, Harayama S (1995) PCR Amplification and direct sequencing of GyrB genes with universal primers and their application to the detection and taxonomic analysis of Pseudomonas putida strains. Appl Environ Microbiol 61:1104-1109

Submitted: November 5, 2007; Accepted: May 2, 2008

Proofs received from author(s): September 3, 2008 